\title{
The Relationship between Academic Optimism Levels of Schools and Their Levels of Openness to Change
}

\author{
Çağlar ÇAĞLAR*
}

Received: 11 February 2013

Accepted: 14 November 2013

\begin{abstract}
The sample of this survey study consisted of 605 teachers (208 female and 397 male). It aims to determine the relationship between academic optimism levels of schools and their levels of openness to change and to detect whether those differ on selected variables such as gender, subject matter taught, teaching experience, and school type, number of teachers and students in school, and type of school graduated. Data were collected through the "Personal Information Form”, “Academic Optimism Scale of Schools" and "Openness to Change Scale of Schools”. Findings indicated that schools' levels of academic optimism and openness to change differed significantly on gender, subject matter taught, school type, number of teachers and students in school. It was also found out that there was a positive and moderate level relationship between schools' levels of academic optimism and openness to change. Academic optimism was also a significant predictor of openness to change. To conclude, it can reasonably be asserted that efforts to higher academic optimism levels of schools can higher their levels of openness to change.
\end{abstract}

Key words: Academic optimism, change, openness to change, school.

\section{Extended Abstract}

Purpose and Significance: Individual needs that have differed in parallel to economical, technological and cultural changes and increasing demands of people toward education have pushed educational institutions for changing themselves and reconsidering their roles. There is a reciprocal relationship between education and change; education is not only affected by social changes, but it also acts as pioneer in social renewal and development, and hence, it can be argued that the relationship between those two is bidirectional (Ozdemir, 2000). It is required that any attempt to hold a change in educational system should initially be accepted by a set of groups like students, teachers, directors and parents (Fullan, 1982, cited in Erdogan, 2000). Since teacher is one of the most strategic components of the social system, namely school (Bursalioglu, 1994), attitudes of teachers toward change do matter greatly to school's improvement. In addition to many other factors, teachers' academic optimism perceptions on learning environment are also effective in teachers' attitudes toward change. In any organization where employees do not believe in the necessity of change, it cannot be assumed that results of change will be positive. Thus, in order to initiate organizational change, determining employees' attitudes toward change might be helpful in blocking potential resistances and planning, implementation and evaluation stages need to be coordinated in line with attitudes of employees. To this end, the current research aims to investigate the relationship between schools' levels of

*Assist. Prof. Dr., Adiyaman University, ccaglar@adiyaman.edu.tr 
academic optimism and of openness to change and to detect whether those differ on selcted variables such as gender, subject matter taught, teaching experience, and school type, number of teachers and students in school, and type of school graduated.

Methods: The population of this study is composed of teachers teaching in elementary and secondary schools in Adryaman and the sample consisted of 625 teachers in total selected through simple random sampling. After cancelling miscompleted and improperly filled forms, the remaining 605 have been included into data analysis.

In this research, data were obtained through the "Personal Information Form", the "School Academic Optimism Scale" (SAOS) developed by Hoy (2006) and adapted into Turkish by Coban and Demirtas (2011) to measure academic optimism; and the “Openness to Change Scale (FCOS)” developed by Smith and Hoy (2007) and adapted into Turkish by Demirtas (2012) to measure openness to change.

Data were analyzed through $t$ tests, one-way variance analyses (ANOVAs), and LSD tests to detect the origin of difference between groups. To determine the effect of independent variables on the dependent variable, regression analysis was performed.

Results: Findings indicated that schools' levels of academic optimism and of openness to change did not differ on subject matter taught, type of school graduated, but differed on gender, teaching experience, school type, number of teachers and students in school. A low-level and positive relationship was found between common competence and openness to change ( $r=.27$ ); between confidence and openness to change ( $r=.39$ ), and between academic stress and openness to change $(r=.49)$. Common competence, confidence and academic stress totally were moderately and significantly correlated with opennes to change $\left(R=.55, R^{2}=.31, p<.01\right)$, and explained $31 \%$ of the variance in openness to change.

Discussion and Conclusions: With respect to the gender variable, despite the fact that both male and female teachers considered that teachers in their schools were highly competent, the mean scores of female teachers were higher than those of male teachers. Regarding the subdimension of confidence, although both groups had moderate levels of confidence, male teachers had higher levels of confidence than did female teachers. With regard to the dimension of openness to change, the mean scores of male teachers were high while those of female teachers were at moderate level. This finding indicated that female teachers' levels of openness to change were lower than those of male teachers.

With respect to the teaching experience variable, both groups had medium levels of confidence. As years of teaching increased, academic stress perceptions also raised and reached its peak among those with at least 21 years of teaching experience. As they gained experience, their levels of expectations also lowered. Hence, they started to perceive learning environments more optimistically as they became more experienced. 
With respect to academic optimism and its subdimensions, the mean scores of science and anatolian high schools and vocational and technical high schools were higher than those of general high schools. teachers' higher levels of academic optimism can be explained by the fact that science and anatolian high school students are selected, class size in science and anatolian high schools is small, these schools provide greater opportunities, and teachers of these schools have higher expectations. the fact that teacher-student communication in vocational and technical high schools is closer might also explain higher levels of academic optimism.

Regarding to openness to change, elementary school and vocational and technical high school teachers' levels of openness to change were high while the mean scores of teachers of general high schools and science and anatolian high schools were at moderate level. This difference might be attributed to the differences in structures of these schools. People who are not uncomfortable with current conditions are not motivated strongly enough to alter those (Ozden, 1998). That is, teachers in both types of schools might experience greater difficulties in their schools.

With respect to the number of teachers variable, teachers in schools with 1-25 or 26-50 teachers perceived that their schools were highly optimistic while teachers in schools with more than 100 teachers had mean scores at moderate level. The fewer number of teachers in these schools provides an environment favorable for close communication which might also positively affect teachers' perceptions of common competence.

With regard to openness to change, the mean scores of teachers in schools with 1-25 or 26-50 teachers were high while teachers in schools with more than 100 teachers had the mean scores at moderate level. Similarly, with respect to the number of students variable, the mean scores of teachers in schools with 1-250 and 251-500 students were high while the mean scores of teachers in schools with more than 1000 students were at moderate level. The reason behind more positive attitudes toward change as the school size decreases might be that teachers take greater part in decision-making processes in small schools. Thus, a more effective communication is established among students, teachers, parents and administrators.

Positive and moderate level correlation between levels of academic optimism and levels of openness to change indicated that levels of openness to change higher as levels of academic optimism higher. Based on this reciprocal relationship, it can be argued that any activity aiming to higher levels of academic optimism perceptions might higher levels of openness to change. To conclude, it can reasonably be asserted that efforts to higher academic optimism levels of schools can higher their levels of openness to change. 


\title{
Okulların Akademik İyimserlik Düzeyleri İle Değişime Açıklık Düzeyleri Arasındaki İlişki
}

\author{
Çağlar ÇAĞLAR*
}

Makale Gönderme Tarihi: 11 Şubat 2013

Makale Kabul Tarihi: 14 Kasım 2013

ÖZET: Tarama modelindeki bu çalışma, 208 kadın, 397 erkek olmak üzere 605 öğretmenin katılımı ile gerçekleştirilmiştir. Araştırmada, okulların akademik iyimserlik düzeyleri ile değişime açıklık düzeyleri arasındaki ilişkinin belirlenmesi, her iki düzeyin; cinsiyet, branş, kıdem, okul türü, okulda çalışan öğretmen sayısı, öğrenci sayısı ve mezun olunan okul türü değişkenlerine göre farklılık gösterip göstermediği incelenmiştir. Araştırmada veri elde etmek için, "Kişisel Bilgi Formu", "Okulların Akademik İyimserlik Ölçeği” ve "Okulların Değişime Açıklık Ölçeği” kullanılmıştır. Bulgular, okulların akademik iyimserlik düzeyleri ile değişime açıklık düzeylerinin; cinsiyet, kıdem, okul türü, okulda çalışan öğretmen ve öğrenci sayısı değişkenlerine göre anlamlı farklılaştıklarını göstermektedir. Okulların akademik iyimserlik düzeyi ile değişime açıklık düzeyi arasında orta düzeyde pozitif bir ilişkinin olduğu ve akademik iyimserliğin değişime açıklığın anlamlı bir yordayıcısı olduğu ortaya çıkmıştır. Sonuç olarak, okulların akademik iyimserlik düzeyini yükseltmeye dönük çabaların değişime açıklık düzeyini yükseltebileceği söylenebilir.

Anahtar Sözcükler: Akademik iyimserlik, değişim, değişime açıklık, okul.

\section{Giriş}

Yaşanan ekonomik, teknolojik ve kültürel değişmelerle birlikte farklılaşan bireysel ihtiyaçlar ve insanların eğitime olan taleplerinin artışı, eğitim örgütlerini değişmeye ve rollerini yeniden gözden geçirmeye zorlamaktadır. Eğitim ve değişim arasında; eğitimin hem toplumdaki değişmelerden etkilenmesi hem de toplumun yenileşmesine ve gelişimine öncülük etmesi nedeniyle çift yönlü bir etkileşim söz konusudur (Özdemir, 2000). Eğitimde gerçekleştirilecek bir değişim girişiminin öncelikle öğrenci, öğretmen, yönetici ve ebeveyn gibi değişik gruplar tarafından benimsenmesi gerekir (Fullan, 1982, aktaran Erdoğan, 2000). Okul denilen sosyal sistemin en stratejik parçalarından biri öğretmendir (Bursalığlu, 1994). Bu nedenle öğretmenlerin değişime karşı tutumları, okulların gelişimi açısından oldukça önem taşımaktadır. Öğretmenlerin değişime karşı tutumlarının arkasında birçok etken yer almaktadır. Öğretmenlerin öğrenme ortamına ilişkin akademik iyimserlik algılarının bu etkenlerden biri olabileceği düşünülmektedir.

\section{Akademik İyimserlik}

İyimserlik, belirli bir duruma ilişkin ya da bir kişilik özelliği olarak genellenen olumlu beklentiler olarak tanımlanabilir. İyimserler, sonuçlara olabildiğince olumlu bakarlar. Bu nedenle amaçlarına ulaşabilmek için daha fazla çaba harcarlar (Carver \& Scheier, 1998). Akademik iyimserlik; akademik başarının önemli olduğu, öğrencilerin başarma kapasitesine sahip oldukları ve buna ilişkin öğrenci ve velilerle işbirliği yapabileceklerine ilişkin öğretim elemanları arasında paylaşılan bir inanç (McGuigan \& Hoy, 2006), bireysel açıdan bakıldığında ise; öğretmenin, öğrencilerinin akademik başarımlarında bir fark yaratabileceğine ilişkin inancı olarak tanımlanabilir. Yeterlik

\footnotetext{
*Yard. Doç. Dr., Adıyaman Üniversitesi, ccaglar@adiyaman.edu.tr
} 
duygusu, öğrenci ve velilere ilişkin güven duygusu ile öğrenciler için olumlu ve iddialı bir öğrenme ortamı yaratmaya odaklanma, öğretmenin akademik iyimserliğini oluştururken (Hoy, Hoy, \& Kurz, 2008), öğretmenlerin ortak yeterliği, güven duygusu ve akademik vurgu, okulun akademik iyimserliğini oluşturmaktadır (Smith \& Hoy, 2007).

Ortak yeterlik, okulun bir bütün olarak öğrenciler üzerinde olumlu bir etki yaratabilecek etkinlikleri örgütleyebilme ve sürdürebilmeye ilişkin öğretmen değerlendirmelerini ifade etmektedir (McGuigan \& Hoy, 2006). Güven, taraflardan birinin yardımsever, güvenilir, yeterli, dürüst ve açık olma davranışına ilişkin diğer tarafın savunmasız kalmaya gönüllü olması olarak tanımlanabilir (Hoy \& TschannenMoran, 1999). Yüksek bir ortak yeterlik duygusu, öğretmenlere güven verici ve başarısızlık durumlarında gerekli direnç ve esnekliği sağlayıcı bir etki yaratırken (Hoy, Sweetland, \& Smith, 2002); güven, öğrencilerin öğrenme düzeyinde fark yaratan önemli bir özelliktir.

Akademik vurgu, okulun, akademik başarıya ve mükemmelliğe ulaşmaya ilişkin çabalarının derecesidir. Akademik vurgunun olduğu okullarda, öğrenciler için belirlenen amaçlar yüksek ancak ulaşılabilir nitelikte ve öğrenme ortamı düzenli ve ciddidir, öğrenciler zorlu görevler için isteklidirler ve akademik başarıya ilişkin sorumluluk taşırlar (Hoy, Tarter ve Hoy, 2006b). Akademik vurgu, yeterlik ve güven sadece doğalarında ve işlevlerinde değil, aynı zamanda güçleri ve öğrenci başarısı üzerindeki olumlu etkileri konusunda da benzerdirler. Akademik vurgu, akademik iyimserliğin davranışsal boyutunu, yeterlik, bilişsel boyutunu, veli ve öğrencilere güven, duyuşsal boyutunu oluşturmaktadır (Hoy ve diğerleri, 2006b).

Akademik iyimserliğe ilişkin yapılan araştırmalar; akademik iyimserlik ile matematik başarısı, fen başarısı, genel başarı ve okuma yeterliği (Bevel, 2010; Hoy ve diğerleri., 2006a, 2006b; McGuigan, 2005; Nes, Evans,\& Segerstrom, 2009; Smith \& Hoy, 2007;), mesleğe bağll1k (Kurz, 2006), liderlik (Mascall, Leithwood, Straus, \& Sacks, 2008) ve örgütsel bağlllık (Çoban \& Demirtaş, 2011) arasında olumlu bir ilişkinin olduğunu göstermektedir.

\section{Değişime Açıklık}

Değişim, hiçbir doğrultuyu ifade etmeyen yani, ilerleme ya da gerileme biçiminde gerçekleşebilen, bir değer yargısı taşımayan ve önceki durum ya da davranıştan farklılaşma; bir bütünün ögelerinde, ögelerinin birbirleriyle ilişkilerinde öncekine göre nicelik ve nitelikçe gözlenebilir bir farklılığın oluşmasıdır (Helvacı, 2010). Örgütsel değişim, değişen iç ve dış çevre koşulları nedeniyle, örgütün etkililik ve verimliliğini artırmak, günün iş gereklerini yerine getirmek, çalışanların ve müşterilerin beklentilerine cevap vermek amacıyla bütünleşik bir sistem olan örgütün tümünde ya da alt sistemleri üzerinde, sistemin tüm dinamikleri ve etkileşimi göz önüne alınarak değişiklikler yapılması (Tokat, 1998), mevcut durumun olumlu veya olumsuz farklı bir duruma dönüşmesi olarak (İlğan, 2008) farklı biçimlerde tanımlanabilir. Örgütsel değiş̧me ve gelişme özde yapi, süreç ve davranışların değişmesi demektir (Balcı, 2000). 
“Örgütsel değişim amaçlı bir girişimdir. Örgütsel açıdan değişimin, geleceğe hazır duruma gelme, örgüt üyeleri arasında güven ve karş1lıklı desteği ve olumlu iletişimi sağlama, sorunlara ve tartışmalara çözüm getirme, sinerji yaratma gibi genel amaçları vardır” (Töremen, 2002:187).

Değişme veya değiştirme eyleminin dinamik ögeleri kültür, toplum, psikoloji ve ekonomidir. Bunlardan her birinin değişikliği geliştirici olduğu gibi önleyici özellikleri de vardır. Değişimi engelleyen etmenler; çeşitli plan, program ve davranışlar hakkında bilgisizlik, işbirliği sağlanmasında becerisizlik, ortak amaç ve yüklenmeler yokluğu, yetersiz norm ve yöntemler, kişisel güvenlik endişeleri, yanlış rol ve statü kavramları ve liderlik özelliklerinin yokluğu olarak sıralanabilir (Bursalığlu, 1994).

Toplumun eğitim gereksinimini karşılamak amacıyla kurulan eğitim örgütleri de özellikle son yarım yüzyıl içinde diğer örgütler de olduğu gibi sürekli değişme ve yenileşme baskısı ile karşı karşıyadırlar (Fullan, 2001; Hargreaves, 2002; Wallace, 2004). Bir eğitim örgütü olarak okul, değişim yaratmak, değişmek ve değiştirmek durumundadır. Toplumsal değişmelere göre kendini yenilemek, dahası toplumsal değişmenin motoru olmak durumundadır. Okulda örgütsel değişismin aşamaları, başlatma, uygulama ve birleştirmedir. Başlatma aşaması, problemin tanımlanmasını; çalışanların davranışlarının değiştirilmesini; birleştirme aşaması ise bu davranışların düzenli bir hâle gelmesini sağlama sürecidir (Giacquinta, 1973).

Değişime karşı tutum, geniş bir yelpazeyi oluşturan, değişime hazır olma, değişime karşı direnç, değişime karşı kötümserlik, değişime açıklık, değişimle başa çıkma, değişime uyum, değişimin benimsenmesi ve değişime bağl11ık gibi değişkenler bağlamında ele alınır. Değişime karşı çalışanların tutumlarının yeterince anlaşılmaması ve değişim sırasında genellikle olumsuz olan bu tutumların olumlu tutumlara dönüştürülmesinin ihmal edilmesi değişim süreçlerinde birbirini besleyen olumsuz süreçlere yol açmaktadır (Kondakçı, Zayim, \& Çalışkan, 2010).

Eğitim örgütlerinde değişiklik yapmak güç ve nazik bir eylemdir çünkü eğitim çok amaçlı bir girişimdir (Bursalıoğlu, 1994). Yapıda ya da amaçlarda gerçekleştirilecek değişmelere ilk tepki, genellikle öğretmenlerden gelmektedir. Her yeni değişme yeni bilgi, beceri ve iş yüküne neden olmaktadır. Tüm örgütlerde olduğu gibi öğretmenler de bu ek yükü taşımaya karşı isteksiz durumdadırlar (Gökçe, 2000). Değişmenin gerekliliğine inanmayan çalışanların bulunduğu bir örgütte değişme sonuçlarının olumlu olması beklenemez. Bu nedenle, örgütsel değişme çalışmalarına başlamadan önce çalışanların değişmeye yönelik tutumları bilinmelidir. Eğitim örgütlerindeki değişimi farklı açılardan inceleyen önemli sayıda çalışma alanyazında yer almakta (Alıç, 1990; Akpınar \& Aydın, 2007; Argon \& Özçelik, 2008; Aslan, Beycioğlu ve Konan, 2008; Çalık, 2003; Gökçe, 2004; Kalmaz, 2007; Kaşkaya, 2007; Kurşunoğlu \& Tanrı̈ğen, 2007; Taş, 2009) ise de değişime açıklık ile akademik iyimserlik kavramları arasındaki ilişkiyi inceleyen herhangi bir çalışmaya ulaşılamamıştır. Okulların değişime açıklık düzeyinin belirlenmesi ve bu düzeyin yükseltilmesi, olası direnişlerin önlenebilmesi ve çalışanların tutumları doğrultusunda planlama, uygulama ve değerlendirme çalışmalarının yapılabilmesi açısından önemlidir (Kurşunoğlu \& Tanrı̈ğen, 2007). 
Okullardaki akademik iyimserlik düzeyinin, okulların değişime açıklık düzeyi üzerinde bir etki yarattığı düşünülmektedir. Bu etki, okulların değişime açıklık düzeyinin yükseltilmesinde önemli bir işlev görebilir.

\section{Amaç}

$\mathrm{Bu}$ araştırmada, öğretmen algılarına göre, okulların akademik iyimserlik düzeyi ile değişime açıklık düzeyi arasındaki ilişkinin ve her iki düzeyin; cinsiyet, branş, kıdem, okul türü, çalışılan kurumdaki öğretmen ve öğrenci sayısı ile mezun olunan okul türü değişkenlerine göre farklılık gösterip göstermediğinin belirlenmesi amaçlanmıştır.

\section{Yöntem}

Araştırmanın modeli, ilişkisel tarama modeline dayalı betimsel bir çalışmadır.

\section{Evren ve Örneklem}

Araştırmanın evrenini, Adıyaman merkez ilçe sınırları içinde bulunan ilk ve ortaöğretim kurumlarında çalışan öğretmenler oluşturmaktadır. Araştırmanın örneklemini ise basit tesadüfi örnekleme yoluyla belirlenen 625 öğretmen oluşturmaktadır. Örneklemde yer alan bütün öğretmenlere veri toplama aracı uygulanmış, hatalı ve eksik doldurulanlar elendikten sonra geriye kalan 605 form değerlendirmeye alınmıştır. Örnekleme ilişsin betimsel istatistikler Tablo 1'de verilmiştir. 
Tablo1

Örnekleme İlişkin Betimsel İstatistikler

\begin{tabular}{|c|c|c|c|}
\hline Değişkenler & & $f$ & $\%$ \\
\hline \multirow{2}{*}{ Cinsiyet } & Kadın & 208 & 34.4 \\
\hline & Erkek & 397 & 65.6 \\
\hline \multirow{4}{*}{ Branş } & Sınıf Öğretmeni & 198 & 32.7 \\
\hline & Sosyal Bilimler & 173 & 28.6 \\
\hline & Fen Bilimleri & 104 & 17.2 \\
\hline & Diğer & 130 & 21.5 \\
\hline \multirow{5}{*}{ Kidem } & $1-5$ y1l & 124 & 20.5 \\
\hline & $6-10 \mathrm{y} 11$ & 107 & 17.7 \\
\hline & $11-15 \mathrm{y} 11$ & 174 & 28.8 \\
\hline & $16-20$ y1l & 104 & 17.2 \\
\hline & 21 yıl ve üzeri & 96 & 15.9 \\
\hline \multirow{5}{*}{ Okul Türü } & İlköğretim & 381 & 63 \\
\hline & Genel Lise & 63 & 10.4 \\
\hline & Fen ve Anadolu Lise & 84 & 13.9 \\
\hline & Mesleki ve Teknik Lise & 71 & 11.7 \\
\hline & Diğer & 6 & 1.0 \\
\hline \multirow{5}{*}{ Öğretmen Sayıs1 } & $1-25$ & 80 & 13.2 \\
\hline & $26-50$ & 251 & 41.5 \\
\hline & $51-75$ & 146 & 24.1 \\
\hline & 76-100 & 111 & 18.3 \\
\hline & 101 ve üzeri & 17 & 2.8 \\
\hline \multirow{5}{*}{ Öğrenci Sayısı } & $1-250$ & 18 & 3.0 \\
\hline & $251-500$ & 87 & 14.4 \\
\hline & $501-750$ & 138 & 22.8 \\
\hline & $751-100$ & 77 & 12.7 \\
\hline & 1001 ve üzeri & 285 & 47.1 \\
\hline \multirow{3}{*}{ Mezun Olunan Okul } & Eğitim Fakültesi & 423 & 69.9 \\
\hline & Fen-Edebiyat Fakültesi & 82 & 13.6 \\
\hline & Diğer & 100 & 16.5 \\
\hline
\end{tabular}

\section{Veri Toplama Aracı}

Kişisel Bilgi Formu. Bu bölümde, araştırmaya katılan öğretmenlerin; cinsiyet, branş, kıdem, okul türü, çalışılan kurumdaki öğretmen ve öğrenci sayısı, mezun olunan okul türü değişkenlerine ilişkin maddeler yer almaktadır.

Okul Akademik İyimserlik Ölçeği. Akademik iyimserliği ölçmek amacıyla Hoy (2006) tarafından geliştirilen, Çoban ve Demirtaş (2011) tarafından Türkçeye uyarlanan "School Academic Optimism Scale" (SAOS) kullanılmıştır. Üç alt boyuttan oluşan ölçeğe ait iç tutarlık değerleri (Cronbach Alpha); birinci boyut için, .68, ikinci boyut için .89 , üçüncü boyut için .86 ve ölçek toplamı için .85 'dir. Güven alt boyutu yedi maddeden oluşmakta ve toplam varyasın \% 37.75'ni, akademik vurgu alt boyutu yedi maddeden oluşmakta ve toplam varyasın \%10.22'sini, özyeterlik alt boyutu beş maddeden oluşmakta ve toplam varyansın \% 8.84'nü açıklamaktadır. Üç boyutun açıkladığı kümülatif varyans oranı ise \% 56.92 olarak bulunmuştur. Bu çalışmada, 
ölçeğe ilişkin iç tutarlık değerleri; birinci boyut için .74, ikinci boyut için .81, üçüncü boyut için, .86 ve ölçeğin toplamı için .85 olarak bulunmuştur.

Okulların Değişime Açıklık Ölçeği. Araştırmada, Smith ve Hoy (2007) tarafından geliştirilen ve Demirtaş (2012) tarafından Türkçeye uyarlanan "Openness To Change Scale (FCOS)” kullanmıştır. Ölçek, üç boyut ve 14 maddeden oluşmaktadır. “Öğretmenlerin değişime açıklı̆̆ı” alt boyutunda beş madde yer almakta ve toplam varyansın \% 35.90'ını, “Müdürlerin değişime açıklı̆̆ı” alt boyutunda altı madde yer almakta ve toplam varyansın \% 15.38'ni, ve “Okul çevresinin değişim baskısı” alt boyutunda ise üç madde yer almakta ve toplam varyansın \% 8.03'ünü açıklamaktadır. Ölçeğin iç tutarlık katsayısı (Cronbach Alpha); öğretmenlerin değişime açıklığı alt boyutu için “.83”, müdürlerin değişime açıklığı alt boyutu için .78, okul çevresinin değişim baskısı alt boyutu için .76 ve ölçeğin geneli için .78 olarak bulunmuştur. Ölçekten alınan puanın yüksekliği, okulların değişime açıklığını, düşük olması ise tersi bir durumu göstermektedir. Bu çalışmada, ölçeğe ilişkin iç tutarlık değerleri; birinci boyut için .94 , ikinci boyut için .85 , üçüncü boyut için, .80 ve ölçeğin toplamı için .90 olarak bulunmuştur.

Tablo 2

Okul Akademik İyimserlik ve Değişime Açılklk Ölçeklerine İlişkin Betimsel Istatistikler

\begin{tabular}{llccccc}
\hline Boyutlar & Madde & $\begin{array}{c}\text { En Düsük } \\
\text { soplam } \\
\text { Puan }\end{array}$ & $\begin{array}{c}\text { En Yüksek } \\
\text { Toplam } \\
\text { Puan }\end{array}$ & $\bar{X}$ & ss \\
\hline \multirow{3}{*}{ Akademik } & Goplu yeterlik & 5 & 5 & 25 & 4.35 & 0.75 \\
İyimserlik & Akademik Vurgu & 7 & 8 & 35 & 2.90 & 0.74 \\
& Toplam & 7 & 7 & 35 & 3.13 & 0.82 \\
\hline \multirow{3}{*}{ Değişime } & Öğretmenlerin Değişime & 5 & 5 & 25 & 3.37 & 1.06 \\
Açılık & Müdürlerin Değişime & 6 & 6 & 30 & 3.81 & 0.99 \\
& Okü Çevresinin Değişim & 3 & 3 & 15 & 3.39 & 0.96 \\
& Toplam & 14 & 17 & 70 & 3.57 & 0.82 \\
\hline
\end{tabular}

\section{Verilerin Analizi}

Çalışmada elde edilen veriler değerlendirilirken bağımsız değişkenler için betimsel analizler yapılmıştır. Varyansların homojen olduğu belirlendikten sonra akademik iyimserlik düzeyi ile değişime açıklık düzeylerinin cinsiyet değişkenine göre farklılaşıp farklılaşmadığını belirlemek için bağımsız gruplar için $t$ testi; branş, kıdem, okul türü, çalışılan kurumdaki öğretmen ve öğrenci sayısı, mezun olunan okul değişkenlerine göre farklılaşıp farklılaşmadığını belirlemekI için ise Tek Yönlü Varyans Analizi (ANOVA) ile gruplar arası farklılığın kaynağını belirlemek üzere LSD testi 
yapılmıştır. Bağımsız değişkenlerin bağımlı değişken üzerindeki etkisini görebilmek amacıyla regresyon analizi yapılmıştır. Puanların yorumlanmasında (1.00-1.79) oldukça düşük düzey, (1.80-2.59) düşük düzey, (2.60-3.40) orta düzey, (3.41-4.21) yüksek düzey, (4.22-5.00) oldukça yüksek düzey aralıkları kullanılmıştır.

\section{Bulgular}

Öğretmenlerin akademik iyimserlik düzeyleri ile değişime açıklık düzeylerinde, branş ve mezun olunan okul türü değişkenlerine göre gruplar arasında anlamlı bir fark görülmez iken cinsiyet, kıdem, okul türü, çalışılan kurumdaki öğretmen ve öğrenci sayısı değişkenlerine göre anlamlı bir fark olduğu belirlenmiştir.

\section{Cinsiyet Değişkenine Göre Akademik İyimserlik ve Değişime Açıklık}

Öğretmenlerin akademik iyimserlik düzeyleri ile değişime açıklık düzeylerinin cinsiyet değişkenine göre farklılaşıp farklılaşmadığını belirlemek amacıyla yapılan $t$ testi sonuçları Tablo 3 'te verilmiştir.

Tablo 3

Okul Akademik Iyimserlik ve Değişime Açıklık Düzeylerinin Cinsiyet Değişkenine Göre Farklılaşıp Farklılaşmadığına Yönelik t Testi Sonuçları

\begin{tabular}{|c|c|c|c|c|c|c|c|}
\hline Boyutlar & & Cinsiyet & $n$ & $\bar{X}$ & Ss & $t$ & $p$ \\
\hline \multirow{4}{*}{$\begin{array}{l}\text { Akademik } \\
\text { İyimserlik }\end{array}$} & \multirow[b]{2}{*}{ Toplu Yeterlik } & Kadın & 208 & 4.47 & 0.71 & \multirow[b]{2}{*}{2.980} & \multirow[b]{2}{*}{$.003 *$} \\
\hline & & Erkek & 397 & 4.28 & 0.08 & & \\
\hline & \multirow[b]{2}{*}{ Güven } & Kadın & 208 & 2.78 & 0.73 & \multirow[b]{2}{*}{-2.908} & \multirow[b]{2}{*}{$.004^{*}$} \\
\hline & & Erkek & 397 & 2.96 & 0.74 & & \\
\hline \multirow{2}{*}{$\begin{array}{l}\text { Değişisime } \\
\text { Açıklık }\end{array}$} & \multirow{2}{*}{$\begin{array}{l}\text { Öğretmenlerin } \\
\text { Değişime } \\
\text { Açıklığ } 1\end{array}$} & Kadın & 208 & 3.25 & 1.08 & \multirow[t]{2}{*}{-2.058} & \multirow[t]{2}{*}{$.040^{*}$} \\
\hline & & Erkek & 397 & 3.43 & 1.04 & & \\
\hline
\end{tabular}

${ }^{*} p<.05$

Tablo 3'te görüldüğü üzere, cinsiyet değişkeni açısından, toplu yeterlik $\left[t_{(603)}=\right.$ 2.980; $p<.05$ ], güven $\left[t_{(603)}=-2.058 ; p<.05\right]$ alt boyutlarında ve öğretmenlerin değişime açıklığ $\left[t_{(603)}=-2.058 ; p<.05\right]$ boyutunda gruplar arasında anlamlı bir fark bulunurken diğer boyutlarda bir fark bulunmamaktadır. Farklar incelendiğinde toplu yeterlik alt boyutunda kadın öğretmenlerin, güven alt boyutunda ve öğretmenlerin değişime açıklı̆̆ boyutunda erkek öğretmenlerin puan ortalamalarının daha yüksek olduğu görülmektedir. 


\section{Kıdem Değişkenine Göre Akademik İyimserlik ve Değişime Açıklık}

Öğretmenlerin akademik iyimserlik düzeyleri ile değişime açıklık düzeylerinin kıdem değişkenine göre farklılaşıp farklılaşmadığını belirlemek amacıyla yapılan analiz sonuçları Tablo 4'te verilmiştir.

Tablo 4

Akademik Iyimserlik ve Değişime Açıklık Düzeylerinin Kldem Değişsenine Göre Farklılaşıp Farklılaşmadığına Yönelik Analiz Sonuçları

\begin{tabular}{|c|c|c|c|c|c|c|c|c|}
\hline \multicolumn{2}{|c|}{ Boyut } & Kidem & $N$ & $\bar{X}$ & Ss & $f$ & $p$ & $\begin{array}{c}\text { Fark } \\
\text { (LSD) }\end{array}$ \\
\hline \multirow{10}{*}{$\begin{array}{l}\text { Akademik } \\
\text { İyimserlik }\end{array}$} & \multirow{5}{*}{ Güven } & $1-5 \mathrm{y} 1 \mathrm{l}$ & 124 & 2.81 & 0.63 & \multirow{5}{*}{3.487} & \multirow{5}{*}{$.008 *$} & 5 \\
\hline & & $6-10$ y1l & 107 & 2.91 & 0.69 & & & 5 \\
\hline & & $11-15$ y1l & 174 & 2.80 & 0.80 & & & \multirow[t]{3}{*}{5} \\
\hline & & $16-20 \mathrm{y} 1 \mathrm{l}$ & 104 & 2.94 & 0.75 & & & \\
\hline & & 21 ve üzeri & 96 & 3.12 & 0.78 & & & \\
\hline & \multirow{5}{*}{$\begin{array}{c}\text { Akademik } \\
\text { Vurgu }\end{array}$} & $1-5$ y1l & 124 & 2.90 & 0.68 & \multirow{5}{*}{3.533} & \multirow{5}{*}{$.007 *$} & \multirow[t]{2}{*}{5} \\
\hline & & $6-10$ y1l & 107 & 2.99 & 0.82 & & & \\
\hline & & $11-15$ y1l & 174 & 3.08 & 0.82 & & & 5 \\
\hline & & $16-20 \mathrm{y} 1 \mathrm{l}$ & 104 & 3,07 & 0,90 & & & 5 \\
\hline & & 21 ve üzeri & 96 & 3,38 & 0,88 & & & \\
\hline
\end{tabular}

${ }^{*} \mathrm{p}<.05$

Tablo 4'te görüldüğü üzere kıdem değişkenine göre; güven $\left[F_{(4,600)}=3.487\right.$; $p<.05]$ ve akademik vurgu $\left[F_{(4,600)}=3.533 ; p<.05\right]$ alt boyutlarında anlamlı bir fark bulunmaktadır. Farkın kaynağına ilişkin yapılan analizde; her iki alt boyutta, 21 yıl ve üzeri kıdeme sahip öğretmenlerin ortalamalarının diğerlerine oranla daha yüksek olduğu görülmektedir.

\section{Okul Türü Değişkenine Göre Akademik İyimserlik ve Değişime Açıklık}

Öğretmenlerin akademik iyimserlik düzeyleri ile değişime açıklık düzeylerinin okul türü değişkenine göre farklılaşıp farklılaşmadığını belirlemek amacıyla yapılan analiz sonuçları Tablo 5'te verilmiştir. 


\section{Tablo 5}

Akademik Iyimserlik ve Değişime Açıklık Düzeylerinin Okul Türü Değişkenine Göre Farklılaşıp Farklılaşmadığına Yönelik Analiz Sonuçları

\begin{tabular}{|c|c|c|c|c|c|c|c|}
\hline Boyut & Okul Türü & $n$ & $\bar{X}$ & Ss & $f$ & $p$ & $\begin{array}{l}\text { Fark } \\
\text { LSD }\end{array}$ \\
\hline \multirow{5}{*}{ Akademik İyimserlik } & İlköğretim Okulu & 381 & 3.36 & 0.54 & \multirow{5}{*}{2.389} & \multirow{5}{*}{$.050 *$} & 2 \\
\hline & Genel Lise & 63 & 3.19 & 0.54 & & & $3<4$ \\
\hline & Fen ve And. Lisesi & 84 & 3.40 & 0.67 & & & \\
\hline & Mesleki ve Tek.Lis. & 71 & 3.48 & 0.53 & & & \\
\hline & Diğer & 6 & 3.34 & 0.91 & & & \\
\hline \multirow{5}{*}{ Toplu Yeterlik (alt boyut) } & İlköğretim Okulu & 381 & 4.42 & 0.74 & \multirow{5}{*}{3.742} & \multirow{5}{*}{$.005 *$} & $2<3$ \\
\hline & Genel Lise & 63 & 4.08 & 0.77 & & & 4 \\
\hline & Fen ve And. Lisesi & 84 & 4.20 & 0.87 & & & \\
\hline & Mesleki ve Tek.Lis. & 71 & 4.38 & 0.63 & & & \\
\hline & Diğer & 6 & 4.17 & 0.50 & & & \\
\hline \multirow{5}{*}{ Güven (alt boyut) } & İlköğretim Okulu & 381 & 2.82 & 0.72 & \multirow{5}{*}{3.215} & \multirow{5}{*}{$.013^{*}$} & $3>4$ \\
\hline & Genel Lise & 63 & 2.93 & 0.67 & & & \\
\hline & Fen ve And. Lisesi & 84 & 3.08 & 0.85 & & & \\
\hline & Mesleki ve Tek.Lis. & 71 & 3.06 & 0.75 & & & \\
\hline & Diğer & 6 & 2.95 & 0.89 & & & \\
\hline \multirow{5}{*}{$\begin{array}{l}\text { Akademik Vurgu (alt } \\
\text { boyut) }\end{array}$} & İlköğretim Okulu & 381 & 3.15 & 0.82 & \multirow{5}{*}{2.786} & \multirow{5}{*}{$.026 *$} & 2 \\
\hline & Genel Lise & 63 & 2.82 & 0.77 & & & $3<4$ \\
\hline & Fen ve And. Lisesi & 84 & 3.16 & 0.89 & & & \\
\hline & Mesleki ve Tek.Lis. & 71 & 3.26 & 0.76 & & & \\
\hline & Diğer & 6 & 3.14 & 0.14 & & & \\
\hline \multirow{5}{*}{ Değişime Açıklık } & İlköğretim Okulu & 381 & 3.63 & 0.75 & \multirow{5}{*}{7.125} & \multirow{5}{*}{$.000 *$} & $2<3$ \\
\hline & Genel Lise & 63 & 3.14 & 0.54 & & & $3<4$ \\
\hline & Fen ve And. Lisesi & 84 & 3.41 & 0.67 & & & 4 \\
\hline & Mesleki ve Tek.Lis. & 71 & 3.79 & 0.53 & & & \\
\hline & Diğer & 6 & 3.43 & 0.91 & & & \\
\hline \multirow{5}{*}{$\begin{array}{l}\text { Müdürün Değişime } \\
\text { Açıklığı (alt boyut) }\end{array}$} & İlköğretim Okulu & 381 & 3.93 & 0.86 & \multirow{5}{*}{9.788} & \multirow{5}{*}{$.000 *$} & $2<3$ \\
\hline & Genel Lise & 63 & 3.23 & 1.20 & & & 4 \\
\hline & Fen ve And. Lisesi & 84 & 3.54 & 1.16 & & & 4 \\
\hline & Mesleki ve Tek.Lis. & 71 & 4.05 & 1.04 & & & \\
\hline & Diğer & 6 & 3.64 & 0.97 & & & \\
\hline \multirow{5}{*}{$\begin{array}{l}\text { Okul Çevresinin Değişim } \\
\text { Baskısı (alt boyut) }\end{array}$} & İlköğretim Okulu & 381 & 3.43 & 0.93 & \multirow{5}{*}{6.160} & \multirow{5}{*}{$.000 *$} & $2<4$ \\
\hline & Genel Lise & 63 & 2.99 & 0.99 & & & 4 \\
\hline & Fen ve And. Lisesi & 84 & 3.21 & 1.01 & & & 4 \\
\hline & Mesleki ve Tek.Lis. & 71 & 3.73 & 0.90 & & & \\
\hline & Diğer & 6 & 3.11 & 1.22 & & & \\
\hline
\end{tabular}

${ }^{*} p<.05$ 
Tablo 5'te görüldüğü üzere, okul türü değişkeni açısından, akademik iyimserlik $\left[f_{(4,600)}=2.389 ; p<.05\right]$ boyutunda, toplu yeterlik $\left[f_{(4,600)}=3.742 ; p<.05\right]$, güven $\left[f_{(4,600)}\right.$ $=3.215 ; p<.05]$ ve akademik vurgu $\left[f_{(4,600)}=2.786 ; p<.05\right]$ alt boyutlarında; değişime açıklık $\left[f_{(4,600)}=7.125 ; p<.05\right]$ boyutunda, müdürlerin değişime açıklı̆̆ $\left[f_{(4,600)}=9.788\right.$; $p<.05]$ ve okul çevresinin değişim baskısı $\left[f_{(4,600)}=1.160 ; p<.05\right]$ alt boyutlarında gruplar arasında anlamlı bir fark bulunmaktadır. Farklılığa ilişkin yapılan analizde akademik iyimserlik boyutunda ve alt boyutlarında; fen ve anadolu, mesleki ve teknik liselerinin puan ortalamalarının diğer okullarınkinden daha yüksek olduğu görülmektedir. Değişime açıklık boyutunda ve alt boyutlarında, mesleki ve teknik lise ile ilköğretim okulu puan ortalamalarının diğerlerinkinden daha yüksek olduğu görülmektedir.

\section{Öğretmen Sayısı Değişkenine Göre Akademik İyimserlik ve Değişime} Açıklık

Öğretmenlerin akademik iyimserlik düzeyleri ile değişime açıklık düzeylerinin öğretmen sayısı değişkenine göre farklılaşıp farklılaşmadığını belirlemek amacıyla yapılan analiz sonuçları Tablo 6'da verilmiştir. 
Tablo 6

Akademik Iyimserlik ve Değişime Açıklık Düzeyinin Öğretmen Sayısı Değişkenine Göre Farklılaşıp Farklılaşmadığına Yönelik Analiz Sonuçları

\begin{tabular}{|c|c|c|c|c|c|c|c|}
\hline Boyut & Öğret. Sayıs1 & $n$ & $\bar{X}$ & Ss & $f$ & $p$ & Fark LSD \\
\hline \multirow{5}{*}{$\begin{array}{l}\text { Akademik } \\
\text { İyimserlik }\end{array}$} & $1-25$ & 80 & 3.44 & 0.60 & \multirow{5}{*}{2.914} & \multirow{5}{*}{$.021 *$} & $4>5$ \\
\hline & $26-50$ & 251 & 3.40 & 0.55 & & & $4>5$ \\
\hline & $51-75$ & 146 & 3.36 & 0.55 & & & 5 \\
\hline & $76-100$ & 111 & 3.27 & 0.59 & & & \\
\hline & 101 üzeri & 17 & 3.04 & 0.38 & & & \\
\hline \multirow{5}{*}{$\begin{array}{l}\text { Toplu Yeterlik (alt } \\
\text { boyut) }\end{array}$} & $1-25$ & 80 & 4.37 & 0.70 & \multirow{5}{*}{3.826} & \multirow{5}{*}{$.004^{*}$} & \\
\hline & $26-50$ & 251 & 4.46 & 0.76 & & & $3<4>5$ \\
\hline & $51-75$ & 146 & 4.12 & 0.82 & & & \\
\hline & $76-100$ & 111 & 4.30 & 0.68 & & & \\
\hline & 101 üzeri & 17 & 3.99 & 0.56 & & & \\
\hline \multirow{5}{*}{$\begin{array}{l}\text { Akademik } \\
\text { Vurgu (alt boyut) }\end{array}$} & $1-25$ & 80 & 3.26 & 0.86 & \multirow{5}{*}{3.149} & \multirow{5}{*}{$.014^{*}$} & $4<5$ \\
\hline & $26-50$ & 251 & 3.18 & 0.81 & & & $4<5$ \\
\hline & $51-75$ & 146 & 3.15 & 0.82 & & & 5 \\
\hline & $76-100$ & 111 & 2.95 & 0.83 & & & 5 \\
\hline & 101 üzeri & 17 & 2.719 & 0.59 & & & \\
\hline \multirow{5}{*}{ Değişime Açıklık } & $1-25$ & 80 & 3.82 & 0.77 & \multirow{5}{*}{9.759} & \multirow{5}{*}{$.000 *$} & $3,4,5$ \\
\hline & $26-50$ & 251 & 3.69 & 0.73 & & & $3,4,5$ \\
\hline & $51-75$ & 146 & 3.39 & 0.77 & & & 5 \\
\hline & $76-100$ & 111 & 3.46 & 0.99 & & & 5 \\
\hline & 101 üzeri & 17 & 3.04 & 0.96 & & & \\
\hline \multirow{5}{*}{$\begin{array}{l}\text { Öğretmenlerin } \\
\text { Değişime Açıklığ } \\
\text { (alt boyut) }\end{array}$} & $1-25$ & 80 & 3.69 & 0.99 & \multirow{5}{*}{6.378} & \multirow{5}{*}{$.000 *$} & $3,4,5$ \\
\hline & $26-50$ & 251 & 3.49 & 1.00 & & & 3,5 \\
\hline & $51-75$ & 146 & 3.08 & 1.05 & & & \\
\hline & $76-100$ & 111 & 3.32 & 1.16 & & & \\
\hline & 101 üzeri & 17 & 2.91 & 0.99 & & & \\
\hline \multirow{5}{*}{$\begin{array}{l}\text { Müdürün Değişime } \\
\text { Açıklığı (alt boyut) }\end{array}$} & $1-25$ & 80 & 4.04 & 0.98 & \multirow{5}{*}{7.557} & \multirow{5}{*}{$.000 *$} & $3,4,5$ \\
\hline & $26-50$ & 251 & 3.94 & 0.87 & & & 3,4 \\
\hline & $51-75$ & 146 & 3.67 & 0.92 & & & 4,5 \\
\hline & $76-100$ & 111 & 3.70 & 1.19 & & & \\
\hline & 101 üzeri & 17 & 2.83 & 1.32 & & & \\
\hline \multirow{5}{*}{$\begin{array}{l}\text { Okul } \\
\text { Çevresinin Değişim } \\
\text { Baskısı (alt boyut) }\end{array}$} & $1-25$ & 80 & 3.60 & 0.96 & \multirow{5}{*}{6.752} & \multirow{5}{*}{$.000 *$} & $3,4,5$ \\
\hline & $26-50$ & 251 & 3.52 & 0.89 & & & $3,4,5$ \\
\hline & $51-75$ & 146 & 3.31 & 0.94 & & & 5 \\
\hline & $76-100$ & 111 & 3.19 & 1.06 & & & 5 \\
\hline & 101 üzeri & 17 & 2.59 & 0.91 & & & \\
\hline
\end{tabular}

$* p<.05$ 
Akademik iyimserlik $\left[f_{(4,600)}=2.914 ; p<.05\right]$ boyutunda, toplu yeterlik $\left[f_{(4,600)}=\right.$ 3.826; $p<.05]$ ve akademik vurgu $\left[f_{(4,600)}=3.149 ; p<.05\right]$ alt boyutlarında; değişime açıklık $\left[f_{(4,600)}=9.759 ; p<.05\right]$ boyutunda, öğretmenlerin $\left[f_{(4,600)}=6.378 ; p<.05\right]$ ve müdürlerin değişime açıklığ $\left.1 \mathrm{f}_{(4,600)}=7.557 ; \mathrm{p}<.05\right]$ ve okul çevresinin değişim baskıs1 $\left[f_{(4,600)}=6.752 ; p<.05\right]$ alt boyutlarında gruplar arasında anlamlı bir fark bulunmaktadır. Farklılığa ilişkin yapılan analizde; tüm boyutlarda, 1-25 ve 26-50 öğretmen mevcudu olan okulların puan ortalamalarının diğerlerinden daha yüksek olduğu görülmektedir. Diğer bir ifadeyle, okullardaki öğretmen mevcudu arttıkça ortalama puanların düştüğü söylenebilir.

\section{Öğrenci Sayısı Değişkenine Göre Akademik İyimserlik ve Değişime Açıklık}

Öğretmenlerin akademik iyimserlik düzeyleri ile değişime açıklık düzeylerinin öğrenci sayısı değişkenine göre farklılaşıp farklılaşmadığını belirlemek amacıyla yapılan analiz sonuçları Tablo 7'de verilmiştir.

Tablo 7

Akademik Iyimserlik ve Değişime Açıklık Düzeyinin Öğrenci Sayısı Değişkenine

\begin{tabular}{|c|c|c|c|c|c|c|c|}
\hline Boyut & Öğr. Sayıs1 & $n$ & $\bar{X}$ & Ss & $f$ & $p$ & Fark LSD \\
\hline \multirow{5}{*}{ Değişime Açıklık } & $1-250$ & 18 & 4.04 & 0.68 & \multirow{5}{*}{6.969} & \multirow{5}{*}{$.000 *$} & $3>5$ \\
\hline & $251-500$ & 87 & 3.78 & 0.77 & & & 5 \\
\hline & $501-750$ & 138 & 3.64 & 0.68 & & & 5 \\
\hline & $751-1000$ & 77 & 3.70 & 0.81 & & & 5 \\
\hline & 1001 üzeri & 285 & 3.40 & 0.88 & & & \\
\hline \multirow{5}{*}{$\begin{array}{l}\text { Öğretmenlerin Değişime } \\
\text { Açıklığı (alt boyut) }\end{array}$} & $1-250$ & 18 & 3.91 & 0.07 & \multirow{5}{*}{4.838} & \multirow{5}{*}{$.001 *$} & $3>5$ \\
\hline & $251-500$ & 87 & 3.62 & 1.08 & & & 5 \\
\hline & $501-750$ & 138 & 3.40 & 0.94 & & & \\
\hline & $751-1000$ & 77 & 3.54 & 1.11 & & & 5 \\
\hline & 1001 üzeri & 285 & 3.20 & 1.09 & & & \\
\hline \multirow{5}{*}{$\begin{array}{l}\text { Müdürün Değişime } \\
\text { Açıklığı (alt boyut) }\end{array}$} & $1-250$ & 18 & 4.29 & 0.75 & \multirow{5}{*}{5.038} & \multirow{5}{*}{$.001 *$} & 5 \\
\hline & $251-500$ & 87 & 4.06 & 0.96 & & & 5 \\
\hline & $501-750$ & 138 & 3.90 & 0.85 & & & 5 \\
\hline & $751-1000$ & 77 & 3.89 & 0.97 & & & \\
\hline & 1001 üzeri & 285 & 3.64 & 1.06 & & & \\
\hline \multirow{5}{*}{$\begin{array}{l}\text { Okul Çevresinin Değişim } \\
\text { Baskısı (alt boyut) }\end{array}$} & $1-250$ & 18 & 3.76 & 0.85 & \multirow{5}{*}{4.056} & \multirow{5}{*}{$.003 *$} & 5 \\
\hline & $251-500$ & 87 & 3.47 & 1.01 & & & 5 \\
\hline & $501-750$ & 138 & 3.50 & 0.82 & & & 5 \\
\hline & $751-1000$ & 77 & 3.60 & 0.95 & & & 5 \\
\hline & 1001 üzeri & 285 & 3.23 & 1.00 & & & \\
\hline
\end{tabular}

${ }^{*} p<.05$

Değişime açıklık $\left[f_{(4,600)}=6.969 ; p<.05\right]$ boyutunda, öğretmenlerin $\left[f_{(4,600)}=\right.$ 4.838; $p<.05]$ ve müdürlerin değişime açıklığ $\left[f_{(4,600)}=5.038 ; p<.05\right]$ ve okul çevresinin değişism baskısı $\left[f_{(4,600)}=4.056 ; p<.05\right]$ alt boyutlarında gruplar arasında anlamlı bir fark 
bulunmaktadır. Farklılığa ilişkin yapılan analizde değişime açıklık boyutunda ve alt boyutlarında, 1000'in üzerinde mevcudu olan okul ortalamasının diğerlerinkinden daha düşük olduğu görülmektedir. Başka bir ifadeyle, öğrenci mevcudu arttıkça değişime açıklık puan ortalamaları düşmektedir.

\section{Akademik İyimserlik Düzeyi ile Değişime Açıklık Düzeyi Arasındaki İlişki}

Okulların akademik iyimserlik düzeylerinin değişime açıklık düzeyleri üzerindeki etkisini görebilmek amacıyla yapılan analiz sonuçları Tablo 8' de gösterilmiştir.

Tablo 8

Akademik Iyimserlik Alt Boyutları ile Değişime Açılık Düzeyine İlişkin Regresyon Analizi Sonuçları

\begin{tabular}{clcccccc}
\hline & Değişkenler & $B$ & $\begin{array}{c}\text { Standart } \\
\text { Hata }\end{array}$ & Beta & $t$ & $p$ & $r$ \\
\cline { 2 - 8 } & Sabit & 11.138 & 2.769 & & 4.023 & & \\
Değişime & Ortak Yeterlik & .708 & .104 & .231 & 6.772 & $.000^{*}$ & .27 \\
Açıklık & Güven & .349 & .094 & .158 & 3.725 & $.000^{*}$ & .39 \\
& Akademik Vurgu & .746 & .085 & .373 & 8.784 & $.000^{*}$ & .49 \\
& $R=.553^{(a)}$ & $R^{2}=.305$ & $R^{2}{ }_{a d j}=.302$ & & & \\
& $F_{(3,601)}=88.048$ & $p=.000$ & & & & \\
\hline
\end{tabular}

Yordayıcı değişkenlerle değişime açıklık arasındaki ikili korelâsyonlar incelendiğinde, ortak yeterlik ile değişime açıklık arasında düşük düzeyde pozitif ( $r=$ .27), güven ile değişime açıklık arasında $(r=.39)$ ve akademik vurgu ile değişime açıklık arasında orta düzeyde pozitif $(r=.49)$ bir ilişkinin olduğu görülmektedir. Ortak yeterlik, güven ve akademik vurgu üçü birlikte orta düzeyde ve anlamlı bir ilişki vermekte $\left(R=.55, R^{2}=.31, p<.01\right)$ ve değişime açıklık puanındaki değişimin \% $31^{\prime}$ ini açıklamaktadır. Standardize edilmiş regresyon katsayısına göre, yordayıcı değişkenlerin etkisi büyükten küçüğe doğru; akademik vurgu, ortak yeterlik ve güven biçiminde siralanmaktadir.

\section{Sonuç ve Tartışma}

$\mathrm{Bu}$ çalışmada, öğretmenlerin algılarına göre okulların akademik iyimserlik düzeyleri ile değişime açıklık düzeyleri arasındaki ilişki araştırılmıştır. Araştırma sonuçları, akademik iyimserlik ve değişime açılık düzeylerinde, cinsiyet, kıdem, okul türü, öğretmen ve öğrenci sayıları değişkenleri açısından farklılaştığını, akademik iyimserliğin değişime açıklığı yordadığını göstermektedir.

Cinsiyet değişkeni açısından; kadın ve erkek öğretmenler, okullarındaki öğretmenleri oldukça yüksek düzeyde yeterli olarak algılamalarına rağmen kadın öğretmenlerin ortalamalarının erkek öğretmenlerinkinden daha yüksek olduğu görülmektedir. Güven alt boyutunda ise her iki grup orta düzeyde güven duymalarına 
rağmen güven düzeyinin erkek öğretmenlerde daha yüksek olduğu görülmektedir. Araştırmanın bu bulgusu, Çoban ve Demirtaş (2011)'in çalışmalarının sonuçları ile paralellik göstermektedir.

Öğretmenlerin değişime açıklık alt boyutunda; erkek öğretmenlerin puan ortalamaları yüksek düzeyde iken kadın öğretmenlerin puan ortalamalarının orta düzeyde olduğu görülmektedir. $\mathrm{Bu}$ durum, kadın öğretmenlerin okullarındaki öğretmenlerin değişime açıklık düzeylerini erkeklere oranla daha düşük algıladıklarını ifade etmektedir. Araştırmanın bu bulgusu, Demirtaş (2012)'nin araştırma sonuçları ile paralellik göstermektedir.

Kıdem değişkeni açısından; güven ve akademik vurgu alt boyutlarında bütün gruplar orta düzeyde güven algılamalarına rağmen, kıdem arttıkça güven ve akademik vurgu algısının yükseldiği ve en yüksek ortalamaya 21 yıl ve daha üzeri kıdeme sahip öğretmenlerin sahip olduğu görülmektedir. Araştırmanın bu bulgusu Çoban ve Demirtaş (2011)'in bulguları ile uyumludur. Öğretmenlerin mesleki kıdemleri arttıkça ortama ilişkin beklentilerinin düşmesi, ortamı daha iyimser algılamalarına yol açıyor olabilir.

Okul türü değişkeni açısından; akademik iyimserlik boyutunda ve alt boyutlarında, fen ve anadolu lisesi ile mesleki ve teknik lise ortalamalarının yüksek, genel lise ortalamalarının orta düzeyde olduğu görülmektedir. $\mathrm{Bu}$ sonuç Çoban ve Demirtaş (2011)'in sonuçları ile çelişmektedir. Fen ve anadolu lisesi öğrencilerinin başarılı öğrenciler arasından seçilerek alınmaları, bu okulların sınıflarının daha az mevcutlu ve olanaklarının daha fazla olması, beklentilerin daha yüksek olması, mesleki ve teknik liselerde ise öğretmen-öğrenci iletişiminin daha yoğun olması gibi nedenler daha yüksek bir akademik öğrenme ortamının oluşmasına yol açmaktadır. Bu durum, öğretmenlerin akademik iyimserlik düzeylerini yükseltiyor olabilir.

Değişime açıklık boyutu ile alt boyutlarında ise ilköğretim ile mesleki ve teknik lise öğretmenlerinin değişime açıklık düzeylerinin yüksek, genel lise ile fen ve anadolu lisesi öğretmenlerinin ortalamalarının orta düzeyde olduğu görülmektedir. Araştırmanın bu bulgusu, Kondakçı ve diğerleri (2010) ile Aslan vd. (2008)'in araştırma sonuçları ile çelişmektedir. Bu farklılaşma, okulların yapısından kaynaklanıyor olabilir. Mevcut durumdan yeterince sıkıntı duymayan insanlar kendilerini o şartları değiştirmek için motive etmezler (Özden, 1998). Ortalamalarının yüksek oluşunun nedeni, her iki okul türünde çalışan öğretmenlerin kurumlarına ilişkin daha fazla sıkıntı yaşamaları olabilir. Öte yandan mesleki ve teknik liselerin teknolojik değişiklikleri yakından izlemek zorunda olmaları bu kurumlarda çalışan öğretmenlerin değişime karşı daha esnek bir tutum geliştirmelerine yol açıyor olabilir.

Öğretmen sayısı değişkeni açısından; akademik iyimserlik boyutunda ve alt boyutlarında, 1-25 ve 26-50 öğretmene sahip okullarda görev yapan öğretmenler, okullarını yüksek düzeyde algılarken, 100'ün üzerinde öğretmeni olan okullarda çalışan öğretmenlerin ortalamalarının orta düzeyde olduğu görülmektedir. Bu bulgu, Çoban ve Demirtaş (2011)'in bulguları ile çelişirken Smith ve Hoy (2007)'nin bulguları ile paralellik göstermektedir. Öğretmen sayısının az oluşu öğretmenlerin birbirlerini daha 
yakından tanıyabilecekleri, iletişimin daha yoğun olduğu bir ortam sağlamaktadır. Ortamın bu özelliği, öğretmenlerin ortak yeterlik algısını olumlu etkiliyor olabilir.

Değişime açıklık boyutunda ve alt boyutlarında, 1-25 ve 26-50 öğretmene sahip okullarda görev yapan öğretmenlerin ortalamaları yüksek düzeyde iken 100’ün üzerinde öğretmeni olan okullarda çalışan öğretmenlerin ortalamalarının orta düzeyde olduğu görülmektedir. Benzer biçimde, öğrenci sayısı değişkeni açısından; değişime açıklık boyutunda ve alt boyutlarında, 1-250 ve 251-500 öğrenci mevcudu olan okullarda görev yapan öğretmenlerin puan ortalamaları yüksek düzeyde iken 1000'in üzerinde öğrenci mevcudu olan okullardaki öğretmenlerin ortalamalarının orta düzeyde olduğu görülmektedir. Okulun büyüklüğünü belirleyen öğretmen ve öğrenci sayısı arttıkça değişime karşı olumlu tutumun azalması, Kondakçı ve diğerleri (2010) tarafından yapılan çalışmanın sonuçları ile çelişmektedir. Küçük okullarda, öğretmenlerin karar verme süreçlerine daha fazla katılmaları, öğrenciler, öğretmenler, veliler ve yöneticiler arasında daha etkili bir iletişim sürecinin olması, daha yakın ilişkilerin kurulabilmesine olanak tanıması, okul ortamında bulunanların birbirlerini daha iyi tanıyabilmeleri bu tür okullarda görev yapan öğretmenlerin değişime daha olumlu tutum geliştirmelerine yol açıyor olabilir.

Okulun akademik iyimserlik düzeyi ile değişime açıklık düzeyi arasındaki orta düzeydeki pozitif ilişki, akademik iyimserlik düzeyi yükseldikçe değişime açıklık düzeyinin yükseldiğini göstermektedir. Bu ilişkiden hareketle, öğretmenlerin okula ilişkin akademik iyimserlik düzeyini yükseltmeye dönük çabaların okulun değişime açıklık düzeyini yükselten önemli sonuçlar yaratacağı ileri sürülebilir. Okulda, öğrenmeyi ve gelişmeyi destekleyici bir kültürün geliştirilmesinin, akademik iyimserlik düzeyini yükselteceği ve değişime karşı daha esnek bir örgütsel ortam yaratacağ söylenebilir.

\section{Kaynakça}

Alıç, M. (1990). Genel liselerde örgütsel değişim ihtiyacı. Eskişehir: Anadolu Üniversitesi Yayınları.

Akpınar, B., \& Aydın, K. (2007). Eğitimde değişim ve öğretmenlerin değişim algıları. Ĕgitim ve Bilim, 144, 71-80.

Argon, T., \& Özçelik, N. (2008). İlköğretim okulu yöneticilerinin değişimi yönetme yeterlikleri. Mehmet Akif Ersoy Üniversitesi Eğitim Fakültesi Dergisi, 8, 70-89.

Aslan, M., Beycioğlu, K., \& Konan, N. (2008). Principals' openness to change in Malatya, Turkey. International Electronic Journal For Leadership in Learning, 12(8), 1-14.

Balcı, A. (2005). Açıklamalı eğitim yönetimi terimleri sözlüğü. Ankara: Tek Ağaç Basım, Yayım, Dağıtım.

Bevel, R. K. (2010). The effects of academic optimism on student academik achievement in Alabama (Unpublished doctoral dissertation). University of Alabama, Alabama.

Bursalığlu, Z. (1994). Okul yönetiminde yeni yapı ve davranış. Ankara: Pegem. 
Çalık, T. (2003). Eğitimde değişimin yönetimi. Milli Eğitim Dergisi, 155-156, 21-31.

Carver, C. S. \& Scheier, M. F. (1998). On the self-regulation of behavior. New York: Cambridge University Press.

Çoban, D., \& Demirtaş, H. (2011). Okulların akademik iyimserlik düzeyi ile öğretmenlerin örgütsel bağlılığı arasındaki ilişki. Kuram ve Uygulamada Eğitim Yönetimi, 17(3), 317-348.

Demirtaş, H. (2012). İlköğretim okullarının değişime açıklığı. İlköğretim Online, 11(1), 18-34.

Erdoğan, İ. (2000). Okul yönetimi ve öğretim liderliği. İstanbul: Sistem Yayıncılık.

Fullan, M. (2001). The new meaning of educational change (3rd ed.). New York: Teacher College Press.

Giacquinta, B.J. (1973). The process of organizational change in schools. Review of Research in Education, 1, 178-208.

Gökçe, F. (2000). Değişme sürecinde devlet ve ĕgitim. Ankara: Eylül.

Gökçe, F. (2004). Okulda değişimin yönetimi. Uludă̆ Üniversitesi Ĕ̆itim Fakültesi Dergisi, 17(2), 211-226.

Hargreaves, A. (2002). Sustainability of educational change: the role of social geographies. Journal of Educational Change, 3(3-4), 189-214.

Helvacı, M. A. (2010). Eğitim örgütlerinde değişim yönetimi. İlke, yöntem ve süreçler. Ankara: Nobel Yayınları.

Hoy, A. W., Hoy, W. K., \& Kurz, N. M. (2008). Teacher's academic optimism: The development and test of a new construct. Teaching and Teacher Education, 24(4), 821-835.

Hoy, W. K., Sweetland, S. R., \& Smith, P. A. (2002). Toward an organizational model of achievement in high schools: The significance of collective efficacy. Educational Administration Quarterly, 38, 77-93.

Hoy, W. K., Tarter, C. J., \& Hoy, A. W. (2006a). Academic optimism of schools. İn W.K.Hoy \& Miskel (Eds.), Contemporary Issues in Educational Policy and School Outcomes,(pp.135-156). Greenwich, CT: Information Age,

Hoy, W. K., Tarter, C. J., \& Hoy, A. W. (2006b). Academic optimism of schools: A force for student achievement. American Educational Research Journal, 43(3), 425-446.

Hoy, W. K. \& Tschannen-Moran, M. (1999). Five faces of trust: An empirical confirmation in urban elementary schools. Journal of School Leadship, 8, 336-359.

İlğan, A. (2008). Örgütsel değişim/ değişme. Milli Ĕgitim Dergisi, 177, 21-31.

Kalmaz, G. (2007). Performans yönetim modelini uygulayan okullarda ögretmen ve yöneticilerin değişim sürecini algılama düzeyleri (Yayınlanmamış yüksek lisans tezi). Yeditepe Üniversitesi, İstanbul. 
Kaşkaya, A. (2007). Örgütsel değişim sürecinde ögretim liderliği (Erzincan İli örneği) (Yayınlanmamış yüksek lisans tezi). Erciyes Üniversitesi, Kayseri.

Kondakçı, Y., Zayim, M., \& Çalışkan, Ö. (2010). Okul yöneticilerinin değişime hazır olma tutumlarının okulun öğretim düzeyi, yöneticilerin deneyimi ve okul büyüklüğü bağlamında incelenmesi. Inönü Üniversitesi Eğitim Fakültesi Dergisi, 11(2), 155-175.

Kurşunoğlu, A., \& Tanriöğen A. (2007). İlköğretim okulu ögretmenlerinin örgütsel değişmeye ilişkin tutumları. 15. Ulusal Eğitim Bilimleri Sempozyumunda sunulmuş sözlü bildiri, Muğla Üniversitesi, Muğla.

Kurz, N. M. (2006). The relationship between teachers' sense of academic optimism and commitment to the profession (Unpublished doctoral dissertation). The Ohio State University, Ohio.

Mascall, B., Leithwood, K., Straus, T., \& Sacks, R. (2008), The relationship between distributed leadership and teachers' academic optimism. Journal of Educational Administration, 46(2), 214-228.

McGuigan, L. \& Hoy, W. K. (2006). Principal leadership: Creating a culture of academic optimism to improve achievement for all students. Leadership and Policy in Schools, 5(3), 203-229.

McGuigan, L. (2005). The role of enabling bureaucracy and academic optimism in academic achievement growth (Unpublished doctoral dissertation). The Ohio State University, Ohio.

Nes, S.L., Evans, D. R., \& Segerstrom, S. C. (2009). Optimism and college retention: Mediation by motivation, performance, and adjustment. Journal of Applied Social Psychology, 39(8), 1887-1912.

Özdemir, S. (2000). Eğitimde örgütsel yenileşme. Ankara: Pegem.

Özden, Y. (2002). Ĕgitimde yeni değerler eğitimde dönüşüm. Ankara: Pegem.

Smith, P. A. \& Hoy, W. K. (2007). Academic optimism and student achievement in urban elementary schools. Journal of Educational Administration, 45(5), 556-568.

Taş, A. (2009). Ortaöğretim okul müdürlerinin değişimi yönetme davranışlarına ilişkin öğretmen algılarının değerlendirilmesi. Inönü Üniversitesi Eğitim Fakültesi Dergisi, 10(2), 1-18.

Tokat, B. (1998). Örgütlerde değişim ve değişimin yönetimi. Kütahya: Dumlupınar Üniversitesi İktisadi ve İdari Bilimler Fakültesi Yayını.

Töremen, F. (2002). Eğitim örgütlerinde değişimin engel ve nedenleri. Firat Üniversitesi Sosyal Bilimler Dergisi, 12(1), 185-202.

Wallace, M. (2004). Orchestrating the complex educational change: Local reorganization of schools in England. Journal of Educational Change, 5(1), 57-78. 